\title{
Renata Gmińska
}

Wyższa Szkoła Bankowa w Gdańsku

e-mail: gminscy@poczta.onet.pl

\section{Grażyna Voss}

Uniwersytet Technologiczno-Przyrodniczy w Bydgoszczy

e-mail: gvoss@wp.pl

\section{AUDYT WEWNECTRZNY - \\ PRZYCZYNY I OBSZAR WDRAŻANIA}

\section{INTERNAL AUDIT - \\ CAUSES AND IMPLEMENTATION AREA}

DOI: $10.15611 /$ pn.2018.513.12

JEL Classification: M42, F36, F65

Streszczenie: Audyt wewnętrzny jest działalnością niezależną i obiektywną, której celem jest przysporzenie wartości i usprawnienie działalności operacyjnej. Obecnie odgrywa coraz większą rolę w funkcjonowaniu organizacji, gdyż umożliwia usprawnienie funkcjonowania podmiotu we wszystkich obszarach działalności oraz identyfikację i podjęcie działań mających na celu ograniczenie ponoszonego ryzyka. Celem artykułu jest określenie przyczyn wdrażania procedur audytu wewnętrznego oraz obszarów objętych audytem. W tym celu przeprowadzono pogłębione studia literaturowe oraz badanie ankietowe. Wyniki przeprowadzonego badania świadczą o tym, że audyt wewnętrzny sprawdza się w różnych jednostkach bez względu na ich wielkość, jak również na rodzaj działalności, chociaż przyczyny jego wdrożenia podyktowane były wymogami związanymi z procedurami ISO i chęcią poprawy jakości pracy. W badanych jednostkach procedury audytu wewnętrznego zostały opracowane i wdrożone we wszystkich obszarach działalności. Jednak najczęściej wdrożenie dotyczyło działalności operacyjnej.

Słowa kluczowe: audyt wewnętrzny, rodzaje i obszary audytu, przyczyny wdrażania.

Summary: Internal audit is an independent and objective activity, the purpose of which is to add value and improve operations. At present, it plays an increasingly important role in the functioning of the organization, as it enables improving the functioning of the entity in all areas of activity as well as identification and undertaking activities aimed at limiting the risk borne. The purpose of the article is to determine the reasons for implementing internal audit procedures and areas covered by the audit. To this end, deepened literature studies and a questionnaire survey were conducted. The results of the conducted research prove that the internal audit works in different units, regardless of their size, as well as the type of activity, although the reasons for its implementation were dictated by the requirements related to ISO 
procedures and the desire to improve the quality of work. In the audited units, internal audit procedures were developed and implemented in all areas of activity. However, most often the implementation concerned operational activities.

Keywords: internal audit, types and areas of audit, reasons for implementation.

\section{Wstęp}

Złożoność transakcji biznesowych, bardziej dynamiczne otoczenie, a także regulacje oraz zalecenia dotyczące ładu korporacyjnego wpływają na wzrost zainteresowania audytem wewnętrznym. Okazuje się bowiem, że kontrola wewnętrzna nie jest w stanie zapewnić sprawnego działania organizacji. To audyt wewnętrzny umożliwia usprawnienie funkcjonowania podmiotu we wszystkich obszarach działalności oraz identyfikację i podjęcie działań mających na celu ograniczenie ponoszonego ryzyka [Milewska-Zawada 2016, s. 247]. Audytor rekomenduje działania zmierzające do poprawy funkcjonowania badanego obszaru czy systemu. Można zatem stwierdzić, że wprowadzenie audytu wewnętrznego stanowi pewnego rodzaju zabezpieczenie jednostki gospodarczej przed niewłaściwym zarządzaniem. To, jakie funkcje i zadania będzie pełnił audyt wewnętrzny w organizacji oraz jakich obszarów będzie dotyczył, zależy od wielkości i struktury organizacji, umiejętności i doświadczenia audytora wewnętrznego, a także od potrzeb zarządzających jednostką gospodarczą. Audyt wewnętrzny może dotyczyć oceny mechanizmów kontroli wewnętrznej procesów finansowych, obszarów operacyjnych organizacji, kontroli systemów IT, a także innych obszarów. Jak pisze Moeller [2011, s. 309]: „Działy audytu wewnętrznego muszą zdefiniować obszar, w obrębie którego można rozważać przeprowadzenie audytu. Lista potencjalnych obszarów do audytu jest często nazywana przestrzenią audytu".

Celem artykułu jest określenie przyczyn wdrażania procedur audytu wewnętrznego oraz obszarów objętych audytem. Aby zrealizować cel, przeprowadzono studia literaturowe oraz badania ankietowe. Dokonano analizy otrzymanych wyników i przedstawiono wynikające $\mathrm{z}$ niej wnioski.

\section{Istota i rodzaje audytu wewnętrznego}

Pojęcie audytu wywodzi się z języka łacińskiego, w którym to znajduje się określenie audire oznaczające słyszeć, słuchać, usłuchać. W starożytnym Rzymie jeden urzędnik porównywał, czyli inaczej przesłuchiwał, odczytując treść dokumentu $\mathrm{z}$ dokumentami drugiego urzędnika. Takie działanie miało zapobiegać błędom i defraudacji pieniędzy. Początki audytu sięgają jednak znacznie wcześniejszego okresu, a mianowicie 3500 p.n.e. Z Mezopotamii pochodzą pierwsze dokumenty potwierdzające weryfikacje danych przez audytorów [Winiarska 2007, s. 9]. Jednak dopiero w okresie rewolucji przemysłowej w Anglii zaczęto kontrolować zgodność zapisów 
w księgach rachunkowych z dokumentami źródłowymi. Początki współczesnego audytu datuje się na lata 40. XX w., kiedy to w Stanach Zjednoczonych utworzono Instytutu Audytorów Wewnętrznych (The Institute of Internal Auditors IIA) [Winiarska 2015, s. 143].

W Encyklopedii PWN audyt określony jest jako „kontrola przedsiębiorstwa pod względem finansowym i organizacyjnym, wycena jego majątku oraz analiza perspektyw jego rozwoju, przeprowadzana przez ekspertów" [Encyklopedia PWN].

Pojęcie audytu jest zdefiniowane także przez polskiego ustawodawcę. Zgodnie $\mathrm{z}$ art. 272 ustawy o finansach publicznych ,audyt wewnętrzny jest działalnością niezależną i obiektywną, której celem jest wspieranie ministra kierującego działem lub kierownika jednostki w realizacji celów i zadań przez systematyczną ocenę kontroli zarządczej oraz czynności doradcze" [Ustawa o finansach publicznych].

Najbardziej znana jest definicja Instytutu Audytorów Wewnętrznych (Institute of Internal Auditors - IIA). Zgodnie z tą definicją , audyt wewnętrzny jest działalnością niezależną i obiektywną, której celem jest przysporzenie wartości i usprawnienie działalności operacyjnej organizacji. Polega na systematycznej i dokonywanej w uporządkowany sposób ocenie procesów: zarządzania ryzykiem, kontroli i ładu organizacyjnego, i przyczynia się do poprawy ich działania. Pomaga organizacji osiągnąć cele dostarczając zapewnienia o skuteczności tych procesów, jak również poprzez doradztwo" [Definicja ... 2016]. Literatura przedmiotu zawiera wiele definicji audytu wewnętrznego. Wynika z nich, że istotą audytu jest obiektywna i niezależna ocena działania organizacji, która pomaga jej w osiąganiu celów [Dittenhofer 2001; Hass $i$ in. 2006]. Obecnie zmieniła się jednak rola audytu wewnętrznego. Jego zadaniem jest zwiększenie (przysporzenie) wartości i usprawnienie działań organizacji. „Audyt wewnętrzny przysparza wartości organizacji (i jej interesariuszom), kiedy dostarcza obiektywnego zapewnienia w istotnych kwestiach oraz przyczynia się do skuteczności i wydajności procesów: ładu organizacyjnego, zarządzania ryzykiem i kontroli” [Definicja... 2016]. Nowa rola audytu wynika między innymi z rosnącej złożoności transakcji biznesowych i bardziej dynamicznego otoczenia. Wśród głównych zadań audytu wymienia się między innymi:

- analizę i ocenę systemu kontroli wewnętrznej,

- identyfikację ryzyk, a także udoskonalenie procesów zarządzania ryzykiem,

- ocenę działań operacyjnych pod względem ich zgodności z celami przedsiębiorstwa,

- przedstawienie kierownictwu opinii i wniosków dotyczących badanych obszarów.

W literaturze zagranicznej, jak i polskiej występują różne klasyfikacje audytu. Wyodrębnia się np. przegląd kontroli wewnętrznej, audyt finansowy, zgodności, operacyjny, śledczy i informatyczny ${ }^{1}$. W Polsce najczęściej jednak wyróżnia się audyt:

${ }^{1}$ Szerzej na temat klasyfikacji audytu w polskiej i zagranicznej literaturze w [Ciak, Voss 2017, s. 241; Łagodzki 2011, s. 389]. 
- finansowy,

- operacyjny,

- informatyczny.

Audyt finansowy dotyczy oceny sprawozdań finansowych zgodnie ze standardami rewizji finansowej. Koncentruje się na wiarygodności sprawozdania finansowego i zgodności z regułami rachunkowości. Jest działaniem ex post. Celem audytu sprawozdań finansowych jest sformułowanie opinii. Zadaniem audytora jest ocena dokładności i zgodności wszystkich informacji, które są w nich zawarte.

Audyt operacyjny koncentruje się na badaniu oszczędności, wydajności i skuteczności systemów i jednostek organizacyjnych danego podmiotu gospodarczego pod względem efektywności zarządzania działalnością operacyjną. W audycie tym dokonuje się oceny osiągnięcia zamierzonych rezultatów do poniesionych kosztów oraz efektywności zarządzania, a zatem ocenia się, w jaki sposób kierownictwo jednostki planuje swoje działania, kontroluje realizację planów i zarządza ryzykiem.

Audyt informatyczny ma na celu dostarczanie kierownictwu jednostki obiektywnych i niezależnych ocen rozwiązań informatycznych i organizacyjnych składających się na systemy informacyjne działające $\mathrm{w}$ organizacji. Przedmiotem oceny $\mathrm{w}$ audycie informatycznym są:

- „kontrola/nadzór nad systemami informacyjnymi organizacji,

- sposób zarządzania przedsięwzięciami informatycznymi,

- konkretne rozwiązania informatyczne (działające lub projektowane)" [Zalewski i in. 2018].

Powyższy podział z audytu wyznacza zarazem obszary, w jakich jest przeprowadzany.

Istotne znaczenie $\mathrm{w}$ przeprowadzeniu audytu wewnętrznego ma odpowiednie umiejscowienie komórki audytu w strukturze przedsiębiorstwa, gdyż realizacja funkcji audytu wymaga odpowiedniego zaplanowania i przeprowadzanych prac audytowych. Plan taki powinien zostać sporządzony na podstawie przeprowadzonej analizy ryzyka oraz priorytetów i przewidywań kierownika jednostki. W celu powołania komórki audytowej niezbędne staje się opracowanie [Herdan i in. 2009, s. 93]:

- planu organizacji i wdrożenia audytu,

- długoterminowego lub rocznego planu audytu,

- standardu i procedur jego przeprowadzania.

Przeprowadzenie zaś audytu można podzielić na kilka etapów, do których zalicza się [Herdan i in. 2009, s. 93-94]:

- analizę obszarów ryzyka,

- planowanie audytu,

- opracowanie programów zadania audytowego,

- przeprowadzenie posiedzenia otwierającego,

- wykonanie zadania audytowego,

- przeprowadzenie posiedzenia zamykającego,

- opracowanie sprawozdania przez audytora,

- przeprowadzenie działań sprawdzających. 
Bez względu na rodzaj audytu (finansowy, operacyjny, informatyczny) występują pewne podobieństwa w jego przeprowadzaniu. Między innymi wykorzystuje się te same techniki, a sam proces audytu i profil audytora jest podobny. Ponadto każdy audyt przeprowadzany jest $\mathrm{w}$ celu zapewnienia odpowiedniej jakości prac z zastosowaniem określonych procedur.

Na tle krótkich rozważań teoretycznych zostaną zaprezentowane wyniki badania ankietowego.

\section{Metodyka badań}

W niniejszym opracowaniu wykorzystano badanie ankietowe, które zostało przeprowadzone w okresie od listopada 2017 do stycznia 2018 r. Przeprowadzono je, wykorzystując przygotowany kwestionariusz badawczy, który poprawnie wypełniło 60 podmiotów gospodarczych. Podmioty te prowadzą swoją działalność w województwach kujawsko-pomorskim i pomorskim. Kwestionariusz badawczy składał się z dwóch części. Pierwsza pozwoliła na charakterystykę jednostek gospodarczych ze względu na formę organizacyjną, wielkość zatrudnienia oraz rodzaj prowadzonej działalności. Druga część dotyczyła audytu wewnętrznego i jego procedur. Pytania z tej części pozwoliły na określenie powodów wdrożenia audytu wewnętrznego, obszarów objętych audytem i sposobów dokumentacji.

Pytania zawarte w kwestionariuszu badawczym miały zamknięty charakter. Część z nich wymagała udzielenia odpowiedzi tak lub nie, jednak w większości przypadków respondent był proszony o wybór jednego lub kilku wariantów spośród tych, które zostały przedstawione.

\section{Wyniki badań}

W badaniu wzięło udział 60 jednostek, z czego 51 jednostek ( $85 \%$ ankietowanych) reprezentujących sektor prywatny i 9 jednostek z sektora publicznego. W jednostkach tych najczęściej występującą formą działalności była działalność produkcyjna - w wypadku $40 \%$ badanych jednostek. $20 \%$ ankietowanych reprezentowało działalność produkcyjno-handlowo-usługową, najrzadziej reprezentowaną formą działalności były podmioty prowadzące działalność usługową - 3,33\%. Szczegółowe informacje na temat prowadzonej działalności zaprezentowano na rysunku 1.

Wielkość badanych jednostek ze względu na liczbę zatrudnianych pracowników została zaprezentowana na rysunku 2. Najczęściej reprezentowaną grupą były jednostki zatrudniające pracowników w przedziale od 51 do 250 osób (22 jednostki).

Wszystkie z badanych jednostek wdrożyły w ostatnich 3 latach procedury audytu wewnętrznego, jednak przyczyny ich wdrożenia były zróżnicowane. Najczęstszą przyczyną wskazywaną przez badane jednostki były wymogi związane z wdrożeniem procedur ISO $(66,67 \%)$, na drugim miejscu wymieniona została chęć poprawy 


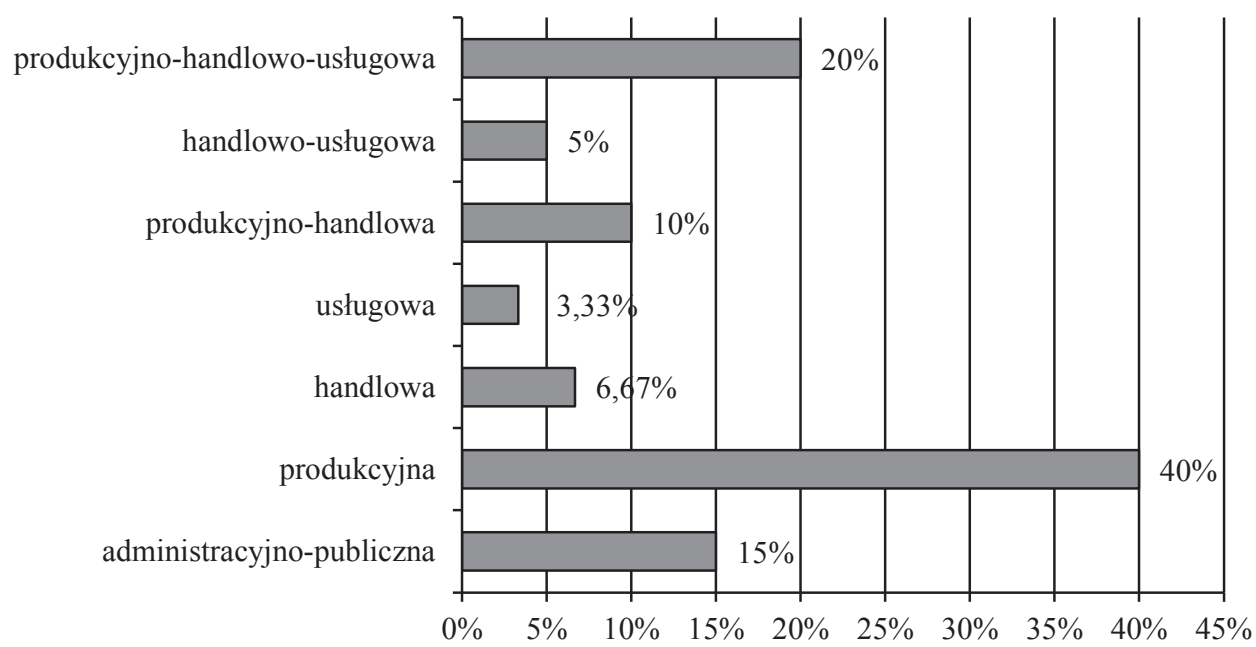

Rys. 1. Rodzaj prowadzonej działalności w badanych jednostkach

Źródło: opracowanie własne na podstawie badania ankietowego.

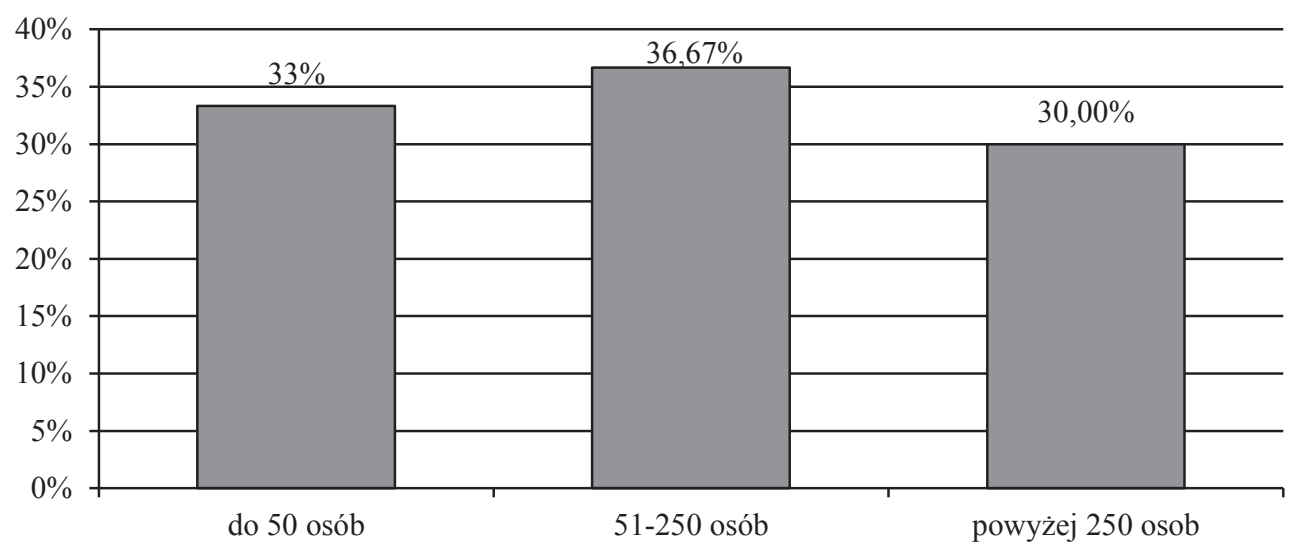

Rys. 2. Wielkość zatrudnienia w badanych jednostkach

Źródło: opracowanie własne na podstawie badania ankietowego.

jakości pracy w jednostkach $(51,67 \%)$. Jedna trzecia badanych wskazuje na zabezpieczenie przed ryzykiem lub zapobieganie nadużyciom, jakie mogłyby się pojawić w jednostce w związku z prowadzoną działalnością. Szczegółowe informacje na temat przyczyn wdrożenia procedur audytu wewnętrznego zaprezentowano na rysunku 3.

W badanych jednostkach procedury audytu wewnętrznego zostały opracowane i wdrożone we wszystkich obszarach działalności. Jednak najczęściej wdrożenie do- 


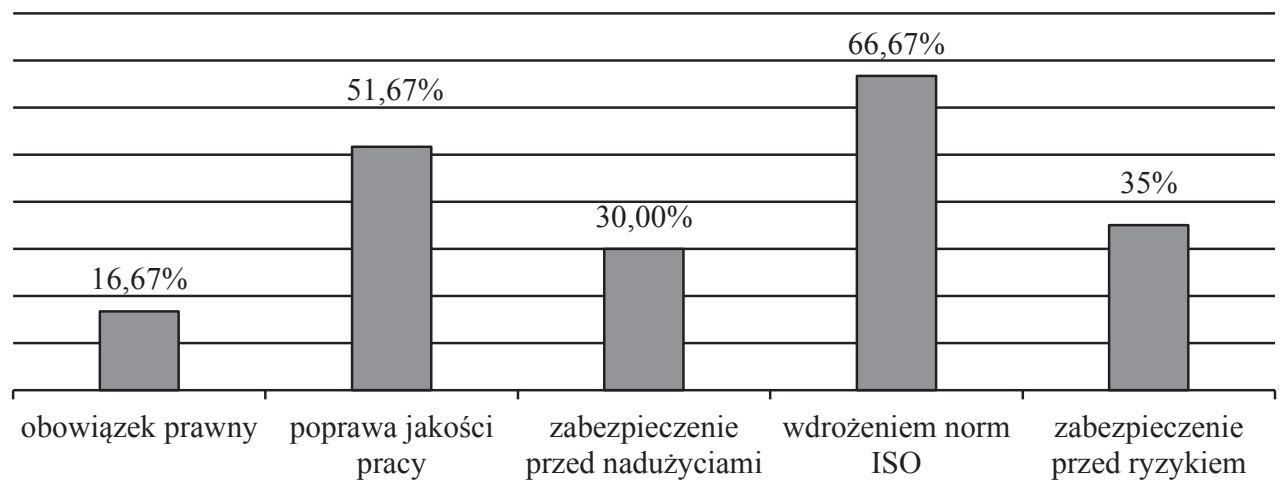

Rys. 3. Przyczyny wdrożenia procedur audytu wewnętrznego

Źródło: opracowanie własne na podstawie badania ankietowego.

tyczyło działalności operacyjnej (73,33\%), rzadziej, bo niewiele ponad połowa badanych jednostek, wdrożyła audyt w działalności finansowej. Respondenci wskazali, że najrzadziej procedurami audytu była obejmowana działalność informatyczna; takie procedury zostały wprowadzone w mniej niż jednej czwartej jednostek. Wyniki dotyczące przyczyn wdrażania audytu zostały zaprezentowane na rysunku 4.

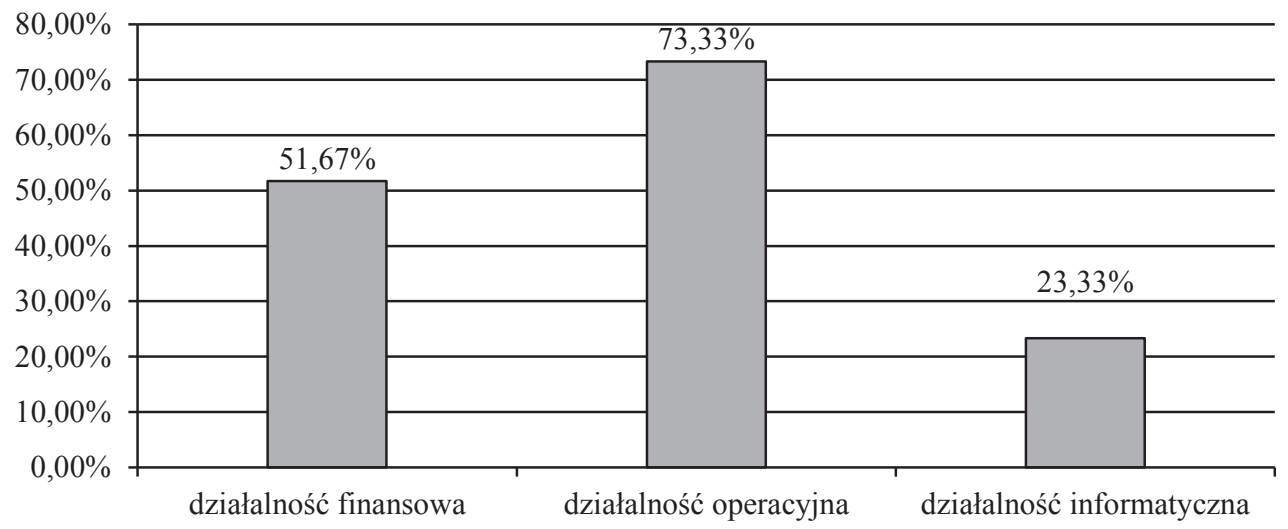

Rys. 4. Obszary działalności objęte wdrożeniem audytu wewnętrznego

Źródło: opracowanie własne na podstawie badania ankietowego.

Pomimo różnych czynników wpływających na wdrożenie procedur audytu i różnych obszarów jego zastosowania poproszono respondentów o wskazanie tych obszarów działalności, w których uznali wdrożenie audytu za najbardziej istotne. W badanych jednostkach najczęściej wdrażany był audyt operacyjny, jednak w opinii respondentów najważniejszym obszarem działalności objętej procedurami audytu jest działalność finansowa (71,67\%) (rys. 5). 


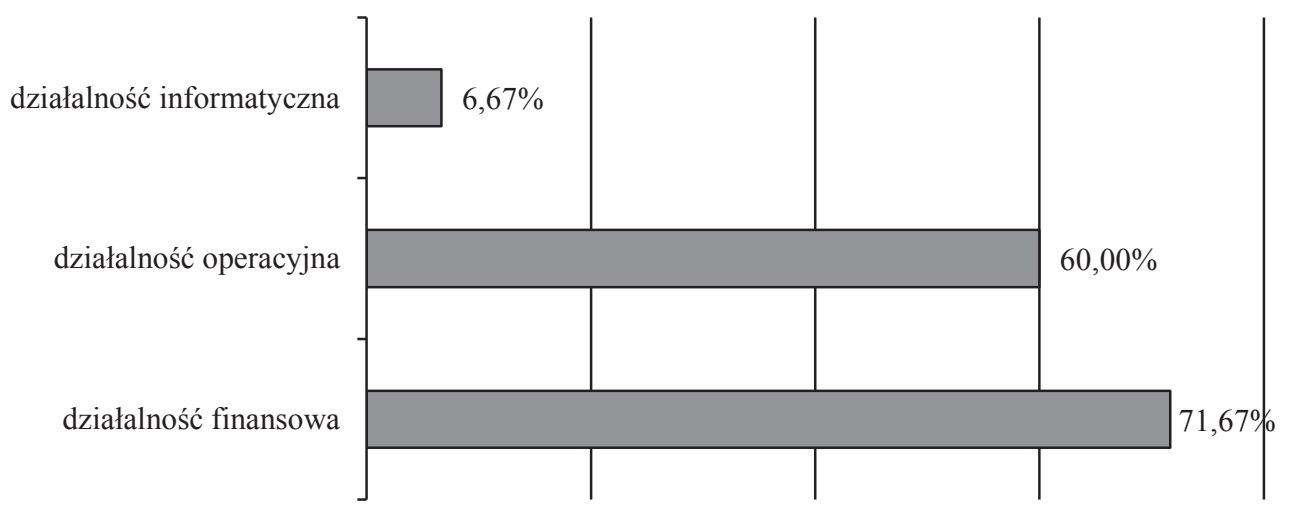

Rys. 5. Najistotniejsze obszary działalności objęte procedurami audytu

Źródło: opracowanie własne na podstawie badania ankietowego.

Zdaniem respondentów w 94\% badanych jednostek wdrożenie procedur audytu wewnętrznego przyczyniło się do poprawy efektywności i skuteczności zarządzania. Świadczy to o pozytywnych aspektach wdrożonych procedur oraz właściwym procesie wdrożenia i zaangażowania pracowników. W podmiotach tych audyt najczęściej przeprowadzany jest na podstawie opracowanego planu i harmonogramu audytu oraz księgi audytu zawierającej procedury postępowania. Sam audyt nie jest jednak przeprowadzany z dala od dobrych praktyk i kodeksu etyki audytora, ale te opracowania są znacznie rzadziej wymieniane przez respondentów (rys. 6).

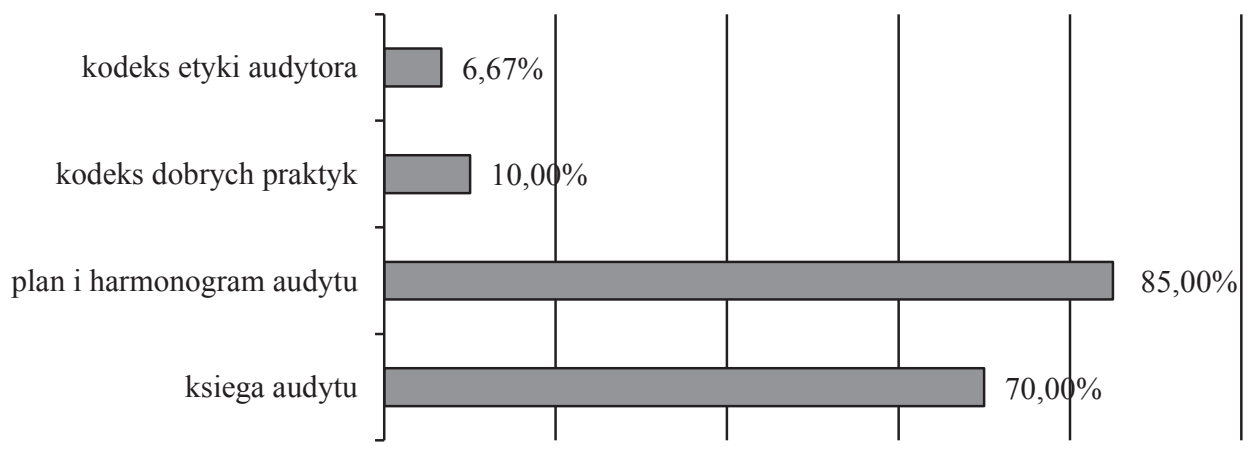

Rys. 6. Rodzaje dokumentów stosowane w pracach audytorów wewnętrznych

Źródło: opracowanie własne na podstawie badania ankietowego.

W celu realizacji zadań audytowych badane jednostki tworzą komórkę audytową (89\% badanych), za działania której odpowiada jej kierownik i współpracuje ze specjalnie zatrudnionymi audytorami ds. działalności operacyjnej, finansowej i informatycznej. Świadczy to o profesjonalnym przygotowaniu jednostek do prac związa- 
nych $\mathrm{z}$ audytem wewnętrznym. Zaledwie $11 \%$ respondentów wskazało, że zleca przeprowadzenie tych prac jednostkom zewnętrznym. Prace związane $\mathrm{z}$ audytem przeprowadzane są $\mathrm{w}$ większości jednostek na podstawie wcześniej opracowanego i zatwierdzonego planu (84\% respondentów), jednak 16\% respondentów wskazało, że częstotliwość pracy audytorów uzależniona jest od bieżących potrzeb jednostki.

Jednostki, w których powstały komórki audytowe, organizują coroczne spotkania z kierownikami wszystkich działów (rys. 7), a celem tych spotkań jest:

- omówienie wyników audytu z poprzedniego roku (81\%),

- omówienie planu na bieżący rok (78\%),

- ustalenie harmonogramu prac na nowy rok $(75 \%)$.

Omówienie zagadnień dotyczących zmian w procedurach

Ustalenie harmonogramu prac na nowy rok

Omówienie planu audytu na bieżący rok

Omówienie wyników audytu z poprzedniego roku

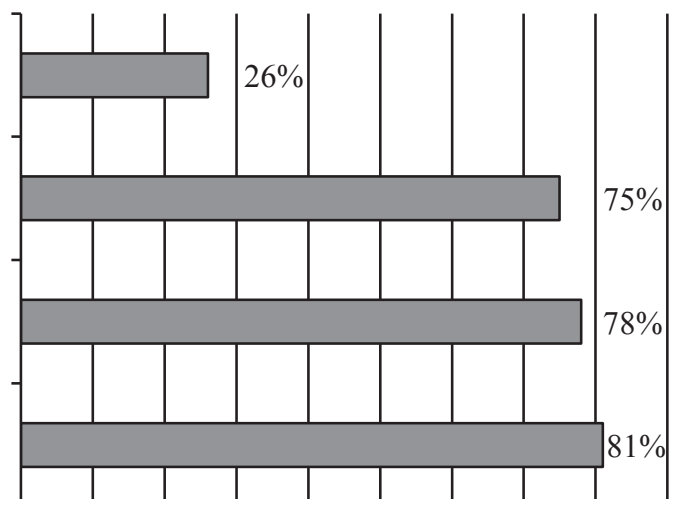

Rys. 7. Najczęściej omawiane zagadnienia związane z audytem wewnętrznym

Źródło: opracowanie własne na podstawie badania ankietowego.

Zdaniem respondentów:

- jednostki z dużym wyprzedzeniem informują i przygotowują pracowników w celu ograniczenia zakłóceń w pracy bieżącej (69\% respondetów),

- audytor wewnętrzny każdorazowo wyjaśnia cel i zakres zadań audytowych $(62 \%$ respondentów),

- wdrożenie i przeprowadzenie audytu powoduje dodatkowe obciążenie dla pracowników działów objętych audytem (46\% respondentów),

- pracownicy mają spsobność, by na bieżąco zgłaszać swoje sugestie w celu usprawnienia procedur i prac audytowych (56\% respondentów).

W kwestionariuszu badawczym zapytano również respondentów o publikowanie informacji na temat audytu wewnętrznego. Zdaniem ankietowanych (69\%) jednostki gospodarcze, które przeprowadzają audyt wewnętrzny, powinny informować użytkowników zewnętrznych na temat przeprowadzonego audytu, w szczególności jakiego obszaru działalności dotyczył i czy w danym roku sprawozdawczym został przeprowadzony. Informacje takie powinny być podawane i publikowane wraz ze sprawozdaniem finansowym. 


\section{Zakończenie}

Procedury audytu wewnętrznego były stosowane w praktyce gospodarczej już w starożytności, jednak wraz z upływem czasu zyskują na znaczeniu [Voss 2015, s. 1600]. Odpowiednie opracowanie procedur i sposób przeprowadzania audytu wpływa na poprawę jakości pracy zarówno w zakresie działalności operacyjnej, jak i finansowej oraz podnoszą efektywność zarządzania [Gleim 2015, s. 2]. Wyniki przeprowadzonego badania świadczą o tym, że audyt wewnętrzny sprawdza się w różnych jednostkach bez względu na ich wielkość, formę prawną, jak również na rodzaj prowadzonej działalności, chociaż przyczyny jego wdrożenia podyktowane były wymogami związanymi z procedurami ISO i chęcią poprawy jakości pracy.

Na szczególną uwagę w badanych jednostkach zasługuje fakt utworzenia w nich komórek audytu wewnętrznego oraz szeregu dokumentów niezbędnych do przeprowadzenia audytu i opracowania systemu przepływu informacji w zakresie prezentacji wyników audytu z poprzedniego roku, a także wspólnego opracowania planu i harmonogramu prac na nowy rok. Działania takie niewątpliwie pozwalają lepiej zrozumieć istotę audytu wszystkim pracownikom i zminimalizować zakres dodatkowych prac z tym związanych.

\section{Literatura}

Ciak J.M, Voss G., 2017, Rola audytu wewnętrznego w sektorze publicznym i prywatnym - wyniki badań w zakresie problemów wdrażania i korzyści z wykorzystania audytu wewnętrznego, Studia Prawno-Ekonomiczne, t. CIV.

Definicja audytu wewnętrznego, Kodeks etyki oraz Międzynarodowe standardy praktyki zawodowej audytu wewnętrznego, thumaczenie na język polski (2016), The Institute of Internal Auditors Research Foundation, Altamonte Springs, FL.

Dittenhofer M., 2001, Internal Audit Effectiveness: An Expansion of Present Methods, „Managerial Auditing Journal", Vol. 16, No. 8.

Encyklopedia.pwn.pl/szukaj/audyt.html (dostęp: 5.02.2018).

Gleim I., 2015, Podstawy audytu wewnętrznego, Warszawa, IIA EY Academy of Business.

Hass S., Abdolmohammadi M.J., Burnaby P., 2006, The Americas Literature Review on Internal. Auditing, „Managerial Auditing Journal”, Vol. 21, No. 8.

Herdan A., Stuss M., Krasodomska J., 2009, Audyt wewnętrzny jako narzędzie wspomagajace efektywny nadzór korporacyjny w spótkach akcyjnych, Wydawnictwo Uniwersytetu Jagiellońskiego, Kraków.

Łagodzki P., 2011, Audyt wewnętrzny: wybrane zagadnienia, Zeszyty Naukowe Uniwersytetu Szczecińskiego. Finanse, Rynki Finansowe, Ubezpieczenia, nr 32.

Milewska-Zawada A., 2016, Audyt wewnętrzny szansq na sukces przedsiębiorstwa, Zeszyty Naukowe PWSZ w Płocku, Nauki Ekonomiczne, t. XXIII.

Moeller R., 2011, Nowoczesny audyt wewnętrzny, Oficyna a Wolters Kluwer business, Warszawa.

Ustawa z 27 sierpnia 2009 r. o finansach publicznych (Dz.U. z 2017 r., poz. 2077). 
Voss G., 2015, Rola i zadania audytu wewnętrznego w zarządzaniu przedsiębiorstwem, TTS Technika Transportu Szynowego, t. 15.

Winiarska K., 2007, Audyt wewnętrzny w 2007 roku. Standardy międzynarodowe - Regulacje krajowe, Difin, Warszawa.

Winiarska K., 2015, Rozwój audytu wewnętrznego na świecie, Zeszyty Naukowe Uniwersytetu Szczecińskiego, nr 864, Finanse, Rynki Finansowe, Ubezpieczenia, nr 76, t. 2.

www.iia.org.pl/sites/default/files/definicja_kodeks_standardy_pl_en_2017_final_0.pdf(dostęp: 3.02.2018). Zalewski A., Cegieła R., Sacha K., Modele i praktyka audytu informatycznego, Wydział Elektroniki i Technik Informacyjnych, Politechnika Warszawska, www.e-informatyka.pl, http://www.einformatyka.pl/attach/Modele_i_praktyka_audytu_informatycznego/479.pdf (dostęp: 4.02.2018 r.). 